\title{
The Life Cycle of Sporing Actinomyces as revealed by a Study of their Structure and Septation
}

\author{
BY EMMY KLIENEBERGER-NOBEL \\ From the Bacteriological Department, Lister Institute, London
}

SUMMARY: A study of the life cycle of four sporing Actinomycetes by Robinow's methods for the demonstration of Feulgen-positive chromatinic structures and of bacterial membranes, reveals two phases of growth in these organisms differing markedly in their morphological structure. These are: the primary or substratum mycelium which, by a special process, produces characteristic cells called 'initial cells', and the secondary or aerial mycelium which arises from the initial cells. The nuclear structures of the secondary mycelium undergo a division by which small rodor dumbbell-shaped structures arise. Two of these appear to fuse, forming the round spore nucleus which, together with cytoplasm and enclosing membrane, represents the spore. The spores in their turn reproduce the primary mycelium.

Recent improvements in the staining of nuclear material and of the membranes and septa of bacteria warrant a re-examination of the changes which these elements undergo during the life cycle of related species or groups. It was with a view to finding new criteria for the purposes of classification that a study of the nuclear structures and septation in Actinomyces was undertaken. So far only a few of these spore-bearing organisms have been examined, but some constant morphological features of their developmental cycle have emerged and are here placed on record.

\section{METHODS OF FIXING AND STAINING}

The nuclear staining technique employed was introduced as a general method for the demonstration of chromatinic material by Robinow (1942, 1944) and applied to certain spore-bearing bacteria by Klieneberger-Nobel (1945). It consists of the treatment of cells fixed in osmic acid with $\mathrm{N}-\mathrm{HCl}$, followed by staining with Giemsa solution. The optimal temperature and time for the acid treatment, as well as the time for staining, varies with different organisms and their stage of growth and are best found by trial. For the Actinomyces the acid was usually applied for $6-20 \mathrm{~min}$. at $55^{\circ}$, the Giemsa stain, diluted 1 in 30 , for about 5-30 min. The specimens were mounted, either in the weak staining solution or in Canada balsam after dehydration with acetone and xylene. In the balsam mounts, the nuclear material stands out with great brilliancy; in watery solutions the cells as a whole are better preserved and cell boundaries as well as cytoplasm are more distinct. In some cases the chromatinic structures showed up clearly when stained for a short time in Giemsa stain only.

The cell boundaries, though occasionally visible in the HCl-Giemsa preparation, are better demonstrated by Robinow's method for the staining of membranes (1944, p. 420). Osmic-acid-fixed preparations were immersed in $5 \%$ watery solution of tannic acid for $30 \mathrm{~min}$., well rinsed in several changes of water, stained for 2-4 min. in crystal violet $1: 10,000$, and mounted in the 
stain or in water. Membranes show up well if treated by this method, though, owing to the precipitation of the tannic acid on the membranous parts, they appear larger than they really are.

\section{ORGANISMS STUDIED}

$A$. gardneri, N.C.T.C. 6531 : spores formed in long chains and whole hyphae transformed into spores.

A. albosporeus, N.C.T.C. 1578: spores mainly formed in the often spirally wound terminal parts of hyphae.

A. chromogenes, N.C.T.C. 1569: only side branches of hyphae form spores.

A. madurae, N.C.T.C. 1070: spores formed by short filaments only.

\section{PREPARATION OF SPECIMENS}

Czapek's medium was mainly used. The addition of a hay decoction (probably rich in amino-acids) greatly enhanced spore formation. In liquid medium coverslips were stood vertically in wide test-tubes, the lower half immersed in the liquid. Some cultures formed flat colonies on the glass surface and thus, on the borderline between the liquid surface and the air, stages of the whole growth cycle up to the formation of the spores were visible on the coverslip. Better preparations were obtained from solid media. An agar plate was inoculated with a spore suspension-dense if young and dilute if older developmental stages were required. Squares of the agar considerably smaller than the coverslip were placed, inoculated side downwards, on to the slip, and a drop of liquid Czapek medium was allowed to run round the edge of the square. The coverslips thus prepared were placed on filter paper in Petri dishes, which were incubated in a moist chamber. In the course of some days an even growth developed in the moist zone round the agar square. The growth, which adhered firmly to the glass surface after the removal of the agar, was fixed in the wet state and after drying was stained as described. It must be emphasized that the success of these preparations depends on the flatness of the growth on the glass surface, for the brilliancy of the staining as well as the definition of the structures are greatly enhanced by the thinness of the film. The low power photograph in Pl. 1, fig. 6, shows the excellent definition obtained over large fields in such preparations.

The optical system used was the same as in the previous work (1945). All photographs were taken by means of the Zeiss photographic eyepiece 'Phoku $9: 12$ '.

\section{THE LIFE CYCLE OF SPORE-BEARING ACTINOMYCETES}

It has been known for a long time that two different phases of growth occur in all spore-forming Actinomycetes, which were designated by Ørskov (1923) as substratum mycelium and aerial mycelium. The substratum mycelium, henceforth referred to as primary mycelium, invariably develops from the spores, but never produces spores itself without first giving rise to an aerial or secondary mycelium, which is either wholly or partly transformed into spores. 
It was found that the primary and secondary mycelia, which differ both in their growth requirements and habit of their filaments, are also conspicuously different in their structural make up.

It was observed that the secondary mycelium was invariably initiated in one particular element, which will be referred to as 'initial cell'. When the secondary hyphae have formed, spore formation, again involving particular structural changes, takes place. The life cycle of the spore-bearing Actinomycetes so far studied is therefore described under the following headings: A. The primary mycelium; B. The origin of the 'initial cells'; C. The secondary mycelium; D. The formation of the spores.

\section{A. The primary mycelium}

The development as far as it is similar in the four organisms examined will be described generally. Features characteristic of one or more organisms will be noted separately.

The mature spore (see below) contains one spherical, relatively large chromatinic body which is surrounded by cytoplasm enclosed in a spore case. One to three, and rarely four, tubules sprout in succession from the spores. The first tubules are always very slender, and irregularly undulating and twisted, a feature often found in fungal hyphae, but not in bacteria. In $A$. gardneri, $A$. albosporeus and $A$. chromogenes the germinating spore is slightly swollen and often elongated and its 'nucleus' has divided into two chromatinic structures (Text-figs. 1, 2 and Pl. 1, figs. 1, 2). In A. madurae the germinating spore is a round swollen body. When the young tubules have reached a certain size they contain small chromatinic granules presumably derived from the two structures found in the germinating spore. These, however, are not wholly used up in the process of germination but are still conspicuous in the spore when the primary mycelium is developed (Text-figs. 3, 4).

As the tubules grow the small nuclear bodies multiply so that the young mycelium is filled with granular or rod-shaped chromatinic bodies (Text-fig. 4 and Pl. 1, fig. 4). Owing to the smallness of these structures no indication could be obtained as to whether they divide by simple fission or by splitting lengthwise in the manner of chromosomes.

In the stages represented by Pl. 1, fig. 3, there are not yet any indications of transverse septa. Nevertheless, septa are formed early in primary mycelia, but they can be demonstrated only by the tannic acid-crystal violet method. Transverse septa seem to originate from small condensations in the outer cell membranes both in the young primary mycelia (Pl. 1, fig. 5) and the secondary mycelia (Pl. 3, fig. 25). Orskov described this development in secondary mycelia but did not observe it in the primary perhaps owing to the less perfect staining by the less adequate methods then available. In Pl. 1, fig. 5, the spore that gave rise to one of the young primary mycelia is to be seen; some of the transverse septa are fully developed, others are only rudimentary. In older hyphae septa are more widely spaced.

Though primary mycelia are septate they never break up into single cells and in this respect differ sharply from the secondary mycelia. 


\section{B. The origin of the 'initial cells'}

When the primary mycelium has reached a certain stage of development, agglomerations of hyphae appear in the form of skeins, network and scrolls. In $\boldsymbol{A}$. gardneri they are compact, nest-like, in others they consist mainly of rolled up end- and side-branches. When $\boldsymbol{A}$. gardner $i$ is grown on the hay decoction
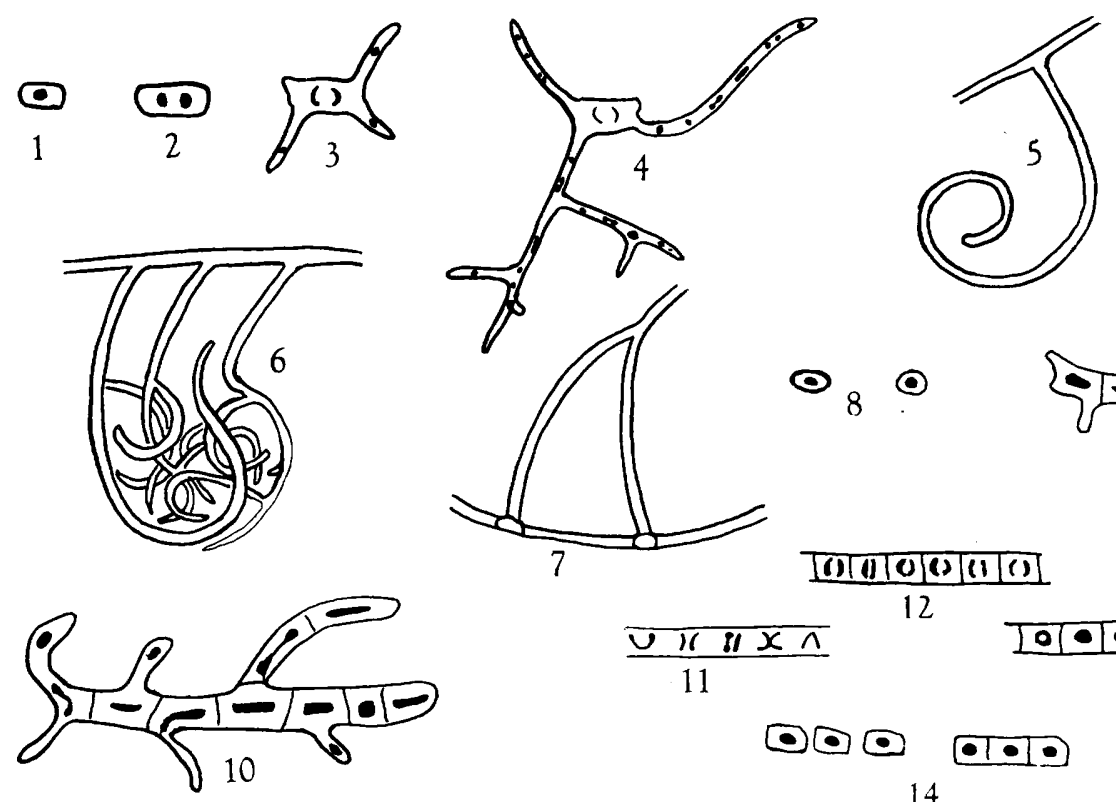

$\odot$
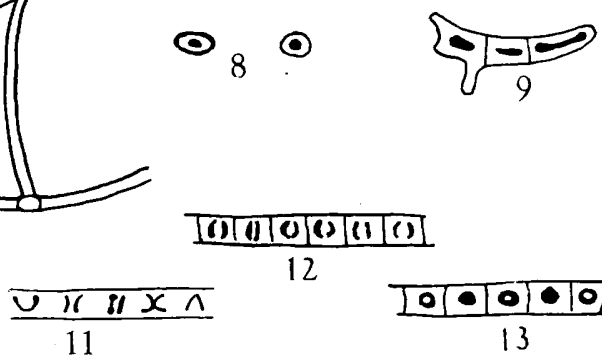

12

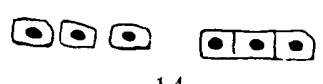

14

Text-figs. 1-14, outlining the life cycle of spore-bearing Actinomycetes.

Text-fig. 1. Resting spore.

Text-fig. 2. Germinating spore. (Type A. gardneri or albosporeus.)

Text-fig. 3. Three germination tubules have been formed.

Text-fig. 4. Young primary mycelium, spore still visible. (Septa not drawn.)

Text-figs. 5, 6. Filaments in 'nest'-formation. (Septa and nuclear structures not drawn.)

Text-fig. 7. Arising of initial cells. (Septa and nuclear structures not drawn.)

Text-fig. 8. Initial cells.

Text-figs. 9, 10. Young secondary mycelia.

Text-fig. 11. Nuclear cylinders of secondary hyphae have split up into 'chromosomes'.

Text-fig. 12. Pairs of 'chromosomes' are going to form the spore nuclei.

Text-fig. 13. Newly formed spores still connected with each other.

Text-fig. 14. Mature spores.

medium which encourages spore formation, the filamentous nests appear on the second day of growth and are conspicuous under low magnification (Pl. 1, figs. 9, 10, and Text-figs. 5, 6). In these areas new cellular elements arise at the points where two filaments are in close contact (Text-fig. 7). In the compact nests of $A$. gardneri the first changes that can be detected are usually darkly staining nuclear granules standing out from the tangled filaments. These granules, which represent the rudiments of the new cells, are surrounded 
by delicately staining cytoplasm and later on develop a membranous outline. Occasionally small 'nests' are found with only a few new cells in the process of formation. In Pl. 2, figs. 14 and 15, two and four respectively of these new cells are to be seen in the centre of converging filaments. Pl. 2, fig. 16, shows a cluster of such new cells in some of which the chromatinic body and the surrounding cytoplasm are clearly visible (see also Text-fig. 8 ). When these cells are fully developed, the filaments from which they arose stain feebly and seem to fade away. The newly formed, brightly staining 'initial cells' elongate and grow into the secondary mycelium.

The second type of initiation can be seen, starting during the first day of incubation, in a vigorously growing culture of $A$. madurae. The filaments either roll up into a scroll and entangle, or very short side branches bend round until their tips make contact with the main branch from which they sprang, thus producing small loops (Text-figs. 5, 6 and Pl. 1, figs. 7, 8). Though the rolling up is the rule in the strain of $A$. madurae studied, network and skein-formation occur as well. Thus a new element may form where two separate cells touch one another as in Pl. 2, fig. 11, where two nodes representing the rudiments of two 'initial cells' have arisen. When these cells elongate and are still in rigid connexion with their parent filaments they are forced to grow into a loop (Pl. 2, fig. 12). If one of the interconnexions gives way (for at that stage the primary mycelium seems to be fragile), the young secondary filament unbends, forming first a hook and then a straight, wide, darkly staining filament (Pl. 2, fig. 13). Initial cells often become wholly separated from the primary mycelium, growing independently to form secondary mycelia on top of the decaying primary filaments.

The condensation of filaments described above is a constant feature in the four species of Actinomyces so far examined. It is seen first at the centre of the colony and later at its periphery. Wherever it arises initial cells develop; these in turn develop into secondary mycelia.

\section{The secondary mycelium}

When the initial cell elongates, its deeply staining chromatinic body develops into an oval or cylindrical structure. This, like the whole cell, seems to divide by a process of fission, forming rows of oval or cylindrical cells. Pl. 2, fig. 18, shows a nest in the centre and rows of brightly stained secondary cells lying on top of the fading primary mycelium in $A$. chromogenes. Here the secondary mycelium is the only conspicuous type of growth. The fully grown hyphae consist of long cells with characteristic, deeply staining chromatinic cylinders, closely resembling the so-called 'fusion cell' of spore-bearing bacilli (Klieneberger-Nobel, 1945). Cells of secondary hyphae of $A$. albosporeus are depicted in Pl. 2, figs. 17, 20, and of $A$. gardneri in Pl. 2, fig. 21.

These mycelia are characterized not only by their chromatinic cylinders but also by their easily stainable transverse septa, which are usually visible in the HCl-Giemsa preparation (Pl. 2, figs. 17, 20) and very conspicuous in preparations stained for cell membranes. Long compartments of a fully grown hypha 
separated by well-defined transverse septa can be seen in Pl. 2, fig. 19. The secondary mycelia are often composed of fairly straight, diverging filaments with fewer side branches than primary mycelia. The side branches, which are produced by sprouting, are slender at first and their nuclear structures often not yet clearly developed, but when fully grown they always resemble the main branch. In Text-figs. 9 and 10, young secondary mycelia are drawn as they appear when stained for nuclei. In Pl. 2, fig. 22, two young secondary mycelia are shown as they appear when stained for cell walls. It should be mentioned that in such preparations the tips of filaments and sprouts are often darkly stained, suggesting a condensation of the membranous substances. Since the secondary hyphae are distinctly septate it is not surprising that they break up readily, and in some organisms, for example in $A$. gardneri, they usually break up into single cells (Pl. 2, fig. 21) which have the same structure and growth potentialities as the cells of unbroken filaments.

\section{The formation of the spores}

The chromatin cylinders of the secondary hyphae change in a characteristic way before the spores are formed. At first they show irregular intersections, and as the divisions develop a more or less regular pattern appears ( $\mathrm{Pl} .2$, fig. 23 and Pl. 3, figs. 24, 28). As outlined diagrammatically in Text-fig. 11, short chromatinic filaments or dumbbells appear lying across the longer axis of the cells. They often occur in pairs, either lying parallel to one another, or in a $\mathbf{V}$ - or X-configuration. In their shape, situation in the cell and arrangement in pairs, these structures strongly resemble the so-called dumbbell bodies or 'chromosomes' of bacteria (Neumann, 1941; Robinow, 1942, 1944; Klieneberger-Nobel, 1945). They are not always clearly demonstrable; sometimes only open loops can be detected; but repeated examinations of similar material provides convincing evidence that division of the chromatinic material occurs regularly whenever spores are being formed. The short filaments, dumbbell bodies or 'chromosomes' set free by this process of division seem to be the elements which later on make up the spore nuclei. It is difficult to decide whether one or two of these elements go to form the chromatin body of each spore, but, since later stages often show two crescent-shaped chromatinic bodies almost forming a ring, it seems justifiable to conclude that two elements go to form the spore nucleus. In the young spore the chromatinic substance usually appears to be disk-shaped with a ring-like condensation of nuclear material at the edge (Pl. 3, fig. 26); later probably by condensation it takes the shape of a sphere (Pl. 3, figs. 27, 29, 30). The changes leading to the formation of the spore are outlined in Text-figs. 12, 13 and 14 .

When the round spore nuclei are being formed in the secondary hyphae, new septa start to develop, subdividing the large compartments into smaller ones as indicated in Pl. 3, fig. 25, and completed in Pl. 3, fig. 33. That each small compartment corresponds to one single spore cell can be seen when fig. 31 is compared to fig. 33 in Pl. 3. Each shows a different sporing side-branch of $A$. chromogenes prepared from the same series of coverslip cultures; in fig. 33 the 
septa, in fig. 31 the nuclei have been stained. It will be seen that in approximately the same length of filament the same number of compartments and nuclei is found. Faintly stained septa of spore compartments can also be detected in Pl. 3, figs. 29, 30, illustrating spores stained for nuclei, while in Pl. 3, fig. 32, two sporing hyphae stained for cell walls are shown; here the septa of the spore cells are very distinct. In the right-hand hypha some cells are in the process of separation and show two membranous borders at the point where they break. Thus each single spore, consisting of a round chromatinic body and surrounding cytoplasm, appears to be enclosed in a spore case.

\section{DISCUSSION}

Most investigators of Actinomycetes have used either stained smears or living material for their studies. As Ørkov pointed out in 1923, smears are very unsatisfactory for elucidating the complex growth of the,ray fungi, on account of tearing and disintegrating the whole culture. On the other hand his improved method of studying the growth on the agar surface-rightly followed by many later workers (see Erikson, 1935) - though not dislocating the culture, does not allow the demonstration of cellular structures, so important for the recognition of a particular stage of growth. The methods used here avoid dislocation and at the same time permit the differentiation of chromatinic bodies, cytoplasm and membranes. Regularly arranged chromatinic structures have hitherto been observed by Badian (1936) and von Plotho (1940). Schaede (1939) was unable to demonstrate any nuclear material in Actinomycetes. Badian was concerned only with the chromatinic material and did not study septation. His interpretation of the changes in the chromatinic matter during development is somewhat speculative and his evidence is not very convincing. Von Plotho, though not realizing the whole complexity of the cycle, described a Feulgen-positive substance in Actinomycetes which concentrated and divided during spore formation. She also observed septation in sporing hyphae. Her description and photomicrographs are in good agreement with those presented above.

Apart from these papers there is little in the literature about a regular cell morphology in Actinomycetes. Two conceptions, which appear to have been generally accepted, may be mentioned. Lieske's and Ørskov's view, that the primary mycelium of Ørskov's group I, comprising the spore-forming organisms, is unicellular, has not been confirmed. Though the primary mycelium does not break up and the septa can be demonstrated neither in the living state, nor when stained without the preceding application of a mordant, transverse septa are undoubtedly present. Secondly, the description of spore formation as found in Lieske's and Ørskov's monographs, that 'Spores are formed from the aerial hyphae without any previous segmentation of the cytoplasm' (Topley \& Wilson, 1946) can no longer stand; for during spore formation the hyphae are separated by transverse septa into small cells, each of which will develop into a spore.

The main features of the developmental cycle of the Actinomycetes studied are outlined in the Text-figs. 1-14, and appear to be as follows: The spore 


\section{Life cycle in Actinomyces}

consists of a round chromatinic body, cytoplasm and a spore case; it germinates by sprouting. Its nuclear body divides into two structures, and partition products of these enter into the germination tubules. The primary mycelium develops further by stretching and sprouting accompanied by division of its small nuclear bodies which are found in all side branches. Eventually the whole primary mycelium is composed of compartments of different length divided from each other by delicate transverse septa and containing probably a variable number of small rod-like or spherical chromatinic bodies. The hyphae of the much-branched primary mycelium are usually more twisted and undulating than those of the secondary mycelium.

As soon as it is well developed the young primary mycelium produces agglomerations of filaments in many areas, first in the centre of the colony and later at the periphery. Where two parts of one filament or two different filaments touch each other new elements arise, which consist of darkly staining nuclear bodies surrounded by cytoplasm and later on enclosed by a cell wall (cf. Lieske's (1921) 'Vierhyphensporen'). For these the name 'initial cells' is proposed since they initiate the secondary mycelium. It is probable that at the points where two filaments make contact with each other the content of two cells, belonging originally to two different hyphae or parts of hyphae, fuse together, so that the initial cell may be regarded as a fusion cell and, in particular, its chromatinic body as a fusion nucleus. Though it was not possible to follow up the process of fusion itself, both the 'nest' formation and the structure of the secondary mycelium favour such an assumption. The elements of which the secondary mycelium is built up closely resemble the so-called fusion cells previously described for certain Clostridia and Bacillus mycoides. They differ however in their origin. In the bacteria the fusion of the chromatinic material takes place in one and the same cellular compartment while in Actinomyces it is supposed that two nuclei or contents of different cells melt together to form the initial cell.

The initial cells grow into the secondary mycelium by a process of sprouting and subdivision of cells. The secondary hyphae are composed of fairly long, cylindrical cells each of which contains a big deeply staining, cylindrical mass of nuclear material. The transverse septa, subdividing the hyphae, are very well defined and easily demonstrable. The hyphae often break up into single cells, particularly in certain species and on certain media. These single cells have exactly the same structure as those of the hyphae and they are able either to grow out again into a new secondary mycelium or to form spores. The conception of the primary mycelia as a haploid phase and the secondary a diploid phase is a promising speculation but in order to prove this an analysis of 'chromosome' content complemented by observations proving the actual fusion of chromatin would be required. Such evidence will be difficult to obtain, since all the elements concerned are of exceedingly small dimensions.

Spore formation begins by division of the nuclear cylinders in the cells of the secondary mycelium. The products of this nuclear division are of definite shape and their arrangement seems to follow a regular pattern. Whereas the 
nuclear cylinders occupy a longitudinal position in the cells, the small rod-like or dumbbell structures derived from them lie across the cells, singly, but more often in pairs, either parallel to one another, or in V-or X-like configurations. Just as the cell of the secondary mycelium resembles the fusion cell of certain spore-bearing bacteria, the small rod-like structures resemble the bacterial 'chromosomes' seen in both the dividing cell and spore formation. It is therefore justifiable to conclude that, unlike the primary mycelium the secondary mycelium has in common with spore-bearing bacteria certain features such as the chromatinic cylinder in the vegetative cell and the chromosome-like rods with their regular arrangement in the spore-forming stage. On the other hand the secondary mycelia of Actinomyces differ from the spore-forming bacteria in their multiplication by sprouting and in the actual formation of the spores. In the spore mother cell of spore-forming bacteria one 'chromosome' develops into the spore nucleus, and the three remaining ones are extruded. In the spore-forming Actinomyces the 'chromosomes' appear to be used up in the process of spore formation, one pair being necessary-if the difficult observations have been rightly interpreted-for the formation of a disk-like or spherical nucleus. In bacteria the big single spore chromosome is at first an open loop and later a disk-like structure before it takes its ultimate position and shape as described by Robinow (1942). Formation of new septa takes place in both groups of organisms; in bacteria, to separate the spore cell from the remainder of the mother cell, in Actinomyces to separate each spore cell from its neighbour in the filament.

The newer methods for the demonstration of cellular structures in bacteria have revealed new features in Actinomycetes, contributing to a better understanding of their life cycle. It is probable that application of the methods to many more species and groups of organisms will shed new light on their position in a natural system of classification of microbes.

\section{REFERENCES}

Badian, J. (1936). Über die zytologische Struktur und den Entwicklungszyklus der Actinomyceten. Acta Soc. Bot. Polon. 13, 105.

Erikson, D. (1935). The pathogenic aerobic organisms of the Actinomyces group. Spec. Rep. Ser. Med. Res. Coun., Lond., no. 203.

Klieneberger-Nobel, E. (1945). Changes in the nuclear structure of bacteria, particularly during spore formation. J. Hyg., Camb., 44, 99.

Lieske, R. (1921). Morphologie und Biologie der Strahlenpilze (Actinomyceten). Leipzig: Borntraeger.

Neumann, F. (1941). Untersuchungen zur Erforschung der Kernverhältnisse bei den Bakterien. Zbl. Bakt. (2. Abt.), 103, 385.

Ørskov, J. (1923). Investigations into the Morphology of the Ray Fungi. Copenhagen: Levin and Munksgaard.

Plotho, O. von (1940). Die chromatische Substanz bei Actinomyceten. Arch. Mikrobiol. 11, 285.

Robinow, C. F. (1942). A study of the nuclear apparatus of bacteria. Proc. Roy. Soc. B, 130, 299. 
Robinow, C. F. (1944). Cytological observations on Bact. coli, Proteus vulgaris and various aerobic spore-forming bacteria, with special reference to the nuclear structures. J. Hyg., Camb., 43, 413.

SchaEde, R. (1939). Zum Problem des Vorkommens von chromatischer Substanz bei Bakterien und Actinomyceten. Arch. Mikrobiol. 10, 472.

Topley, W. W. C. \& Wilson, G. S. (1946). Principles of Bacteriology and Immunity, 3rd ed., revised by G. S. Wilson and A. A. Miles. London: Edward Arnold and Co.

\section{EXPLANATION OF PLATES}

\section{Plate 1}

Figs. 1, 2. A. gardneri; spores germinating after $8 \mathrm{hr}$. at room temperature; HCl-Giemsa. $\times 2000$.

Fig. 3. A. gardneri; spores germinating; tannic acid-crystal violet. $\times 2000$.

Fig. 4. A. gardneri; young primary mycelium; HCl-Giemsa. $\times 2000$.

Fig. 5. A. madurae; primary mycelia, stained for membranes; note original spore in lower left corner; tannic acid-crystal violet. $\times \mathbf{2 0 0 0}$.

Fig. 6. A. albosporeus; secondary hyphae with nuclear cylindrical structures just detectable at low magnification; HCl-Giemsa. $\times 500$.

Figs. 7, 8. A. madurae; primary mycelia forming agglomerations of filaments; Giemsa. $\times 2000$.

Figs. 9, 10. A. gardneri; primary mycelia with 'nests' of tangled filaments; Giemsa. $\times 500$.

Plate 2

Fig. 11. A. madurae; two initial cells developing on primary mycelium; Giemsa. $\times 2000$.

Fig. 12. A. madurae; two initial cells growing into loop-shaped secondary hyphae; Giemsa. $\times 2000$.

Fig. 13. A. madurae; young secondary hyphae unbend and elongate; Giemsa. $\times 2000$.

Fig. 14. A. gardneri; rudiments of two initial cells; HCl-Giemsa. $\times 2000$.

Fig. 15. A. gardneri; rudiments of four initial cells in the centre of converging primary hyphae; HCl-Giemsa. $\times 2000$.

Fig. 16. A. gardneri; young initial cells in nest-like configuration; HCl-Giemsa. $\times 2000$.

Fig. 17. A. albosporeus; secondary hypha; HCl-Giemsa. $\times 2000$.

Fig. 18. A. chromcgenes; initial cells lying on top of primary mycelium and growing into secondary hyphae; HCl-Giemsa. $\times 2000$.

Fig. 19. A. albosporeus; secondary hypha showing septation; tannic acid-crystal violet. $\times 2000$.

Fig. 20. A. albosporeus; secondary hypha showing nuclear cylinders and transverse septa; HCl-Giemsa. $\times 2000$.

Fig. 21. A. gardneri; secondary hypha broken up into single cells; HCl-Giemsa. $\times 2000$.

Fig. 22. A. gardneri; two young sprouting secondary mycelia; tannic acid-crystal violet. $\times 2000$.

Fig. 23. A. albosporeus; the nuclear cylinders have divided up into small filamentous structures which lie across the cells ('chromosome stage'); HCl-Giemsa. $\times 2000$.

\section{Plate 3}

Fig. 24. A. albosporeus; 'chromosome stage' as in 23 ; but not yet quite as well separated; HCl-Giemsa. $\times 2000$.

Fig. 25. A. albosporeus; secondary mycelium showing septation; note the rudiments of new septa which indicate that spores are being formed; tannic acid-crystal violet. $\times 2000$.

Fig. 26. A. albosporeus; two chromatinic filaments or 'chromosomes' seem to form one ring-shaped nucleus each, note also transverse septa; HCl-Giemsa. $\times 2000$. 
Fig. 27. A. gardneri; secondary mycelium in which the round spore nuclei have developed; HCl-Giemsa. $\times 2000$.

Fig. 28. A. albosporeus; 'chromosome stage', note the two crescent-shaped filaments which seem to be drawn apart; HCl-Giemsa. $\times 2000$.

Fig. 29. A. gardneri; the whole secondary mycelium has been transformed into spores; HCl-Giemsa. $\times 2000$.

Fig. 30. A. albosporeus; terminal branches of secondary mycelium have been transformed into spores; HCl-Giemsa. $\times \mathbf{2 0 0 0 .}$

Fig. 31. A. chromogenes; a spore-bearing hypha showing nuclei; HCl-Giemsa. $\times 2000$.

Fig. 32. A. gardneri; secondary mycelium; note two horizontal filaments which have divided up into short spore cells; tannic acid-crystal violet. $\times 1600$.

Fig. 33. A. chromogenes; a spore-bearing hypha showing septation; tannic acid-crystal violet. $\times 2000$.

(Received 3 April 1946) 
Journal of General Microbiology, Vol. 1, No. 1

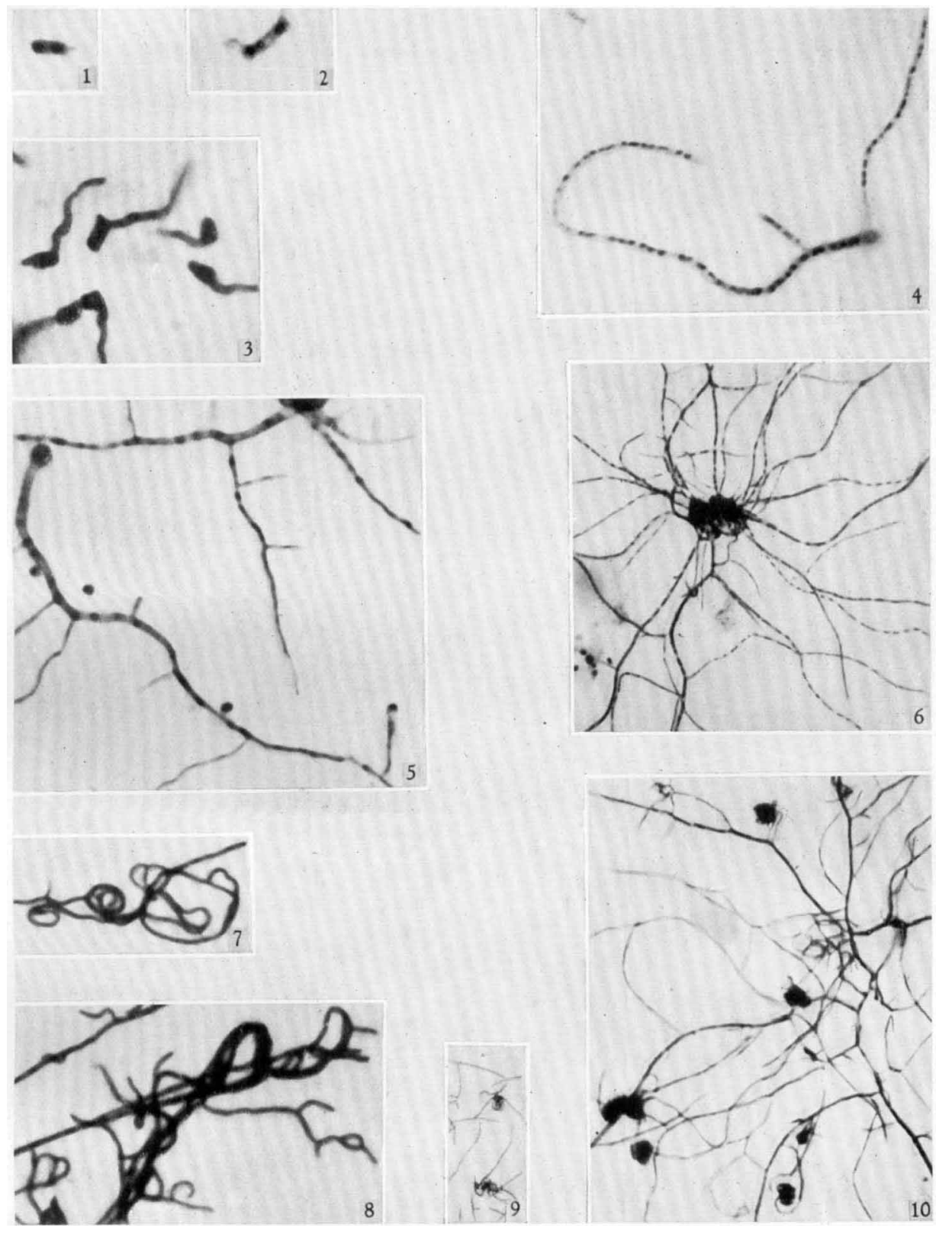

Figs. 1-10

E. Kuieneberger-Nobel--Life cycle in Actinomyces. Plate 1 
Journal of General Microbiology, Vol. 1, No. 1
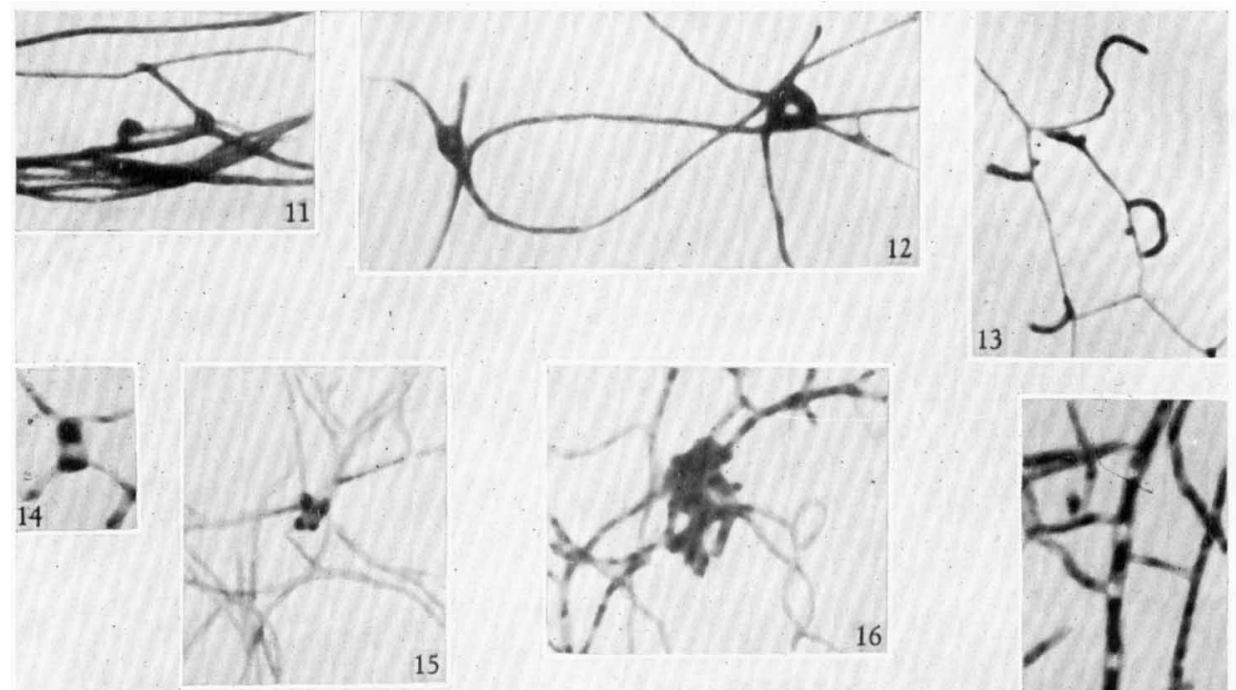

15
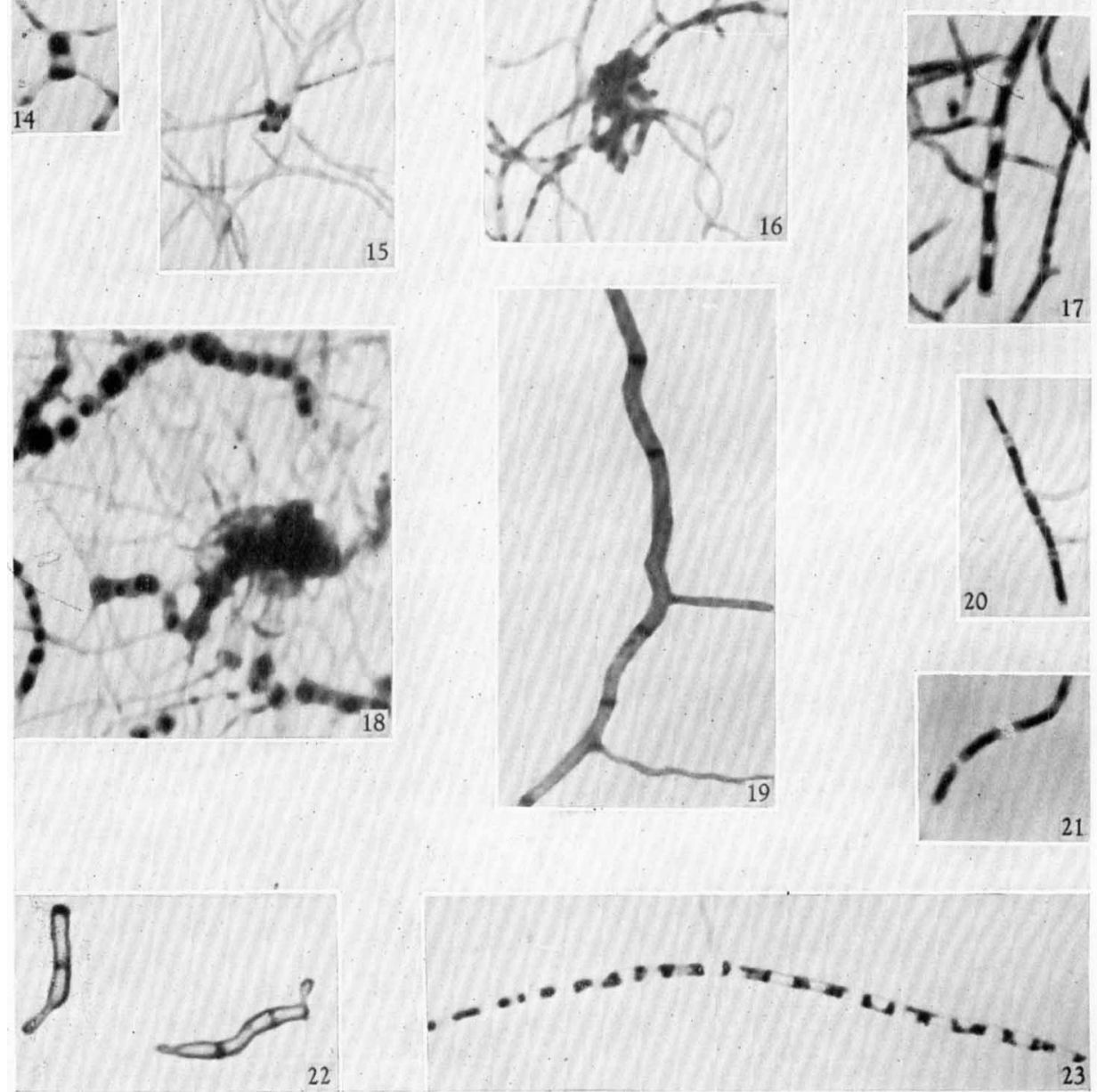

Figs. 11-23

E. Klienebeirger-Nobei--Life cycle in Actinomyces. Plate 2 
Journal of General Microbiology, Vol. 1, No. 1
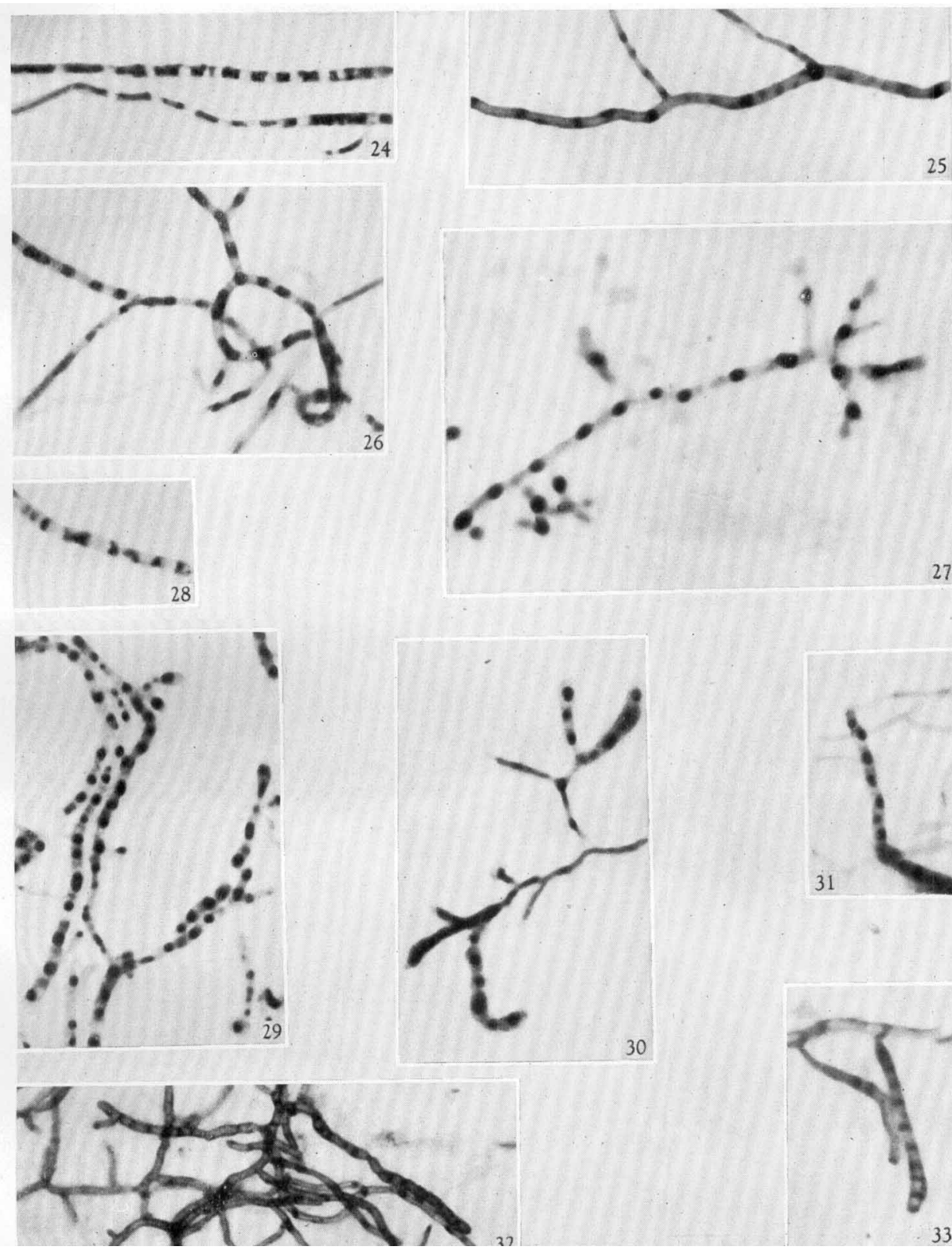

30

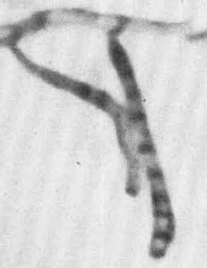

Figs. 24-33

E. Kliteneberger-Nobel-Life cycle in Actinowyens. Plate 3 